\title{
Antimicrobial and Phytochemical Activity of Coconut Shell Extracts
}

\author{
Gebila Mazaya $^{1, a}$, Karseno ${ }^{1, b, *}$, Tri Yanto ${ }^{1, c}$ \\ ${ }^{I}$ Department of Food Science and Technology, Faculty of Agriculture Jenderal Soedirman University, Purwokerto, Indonesia \\ *Corresponding author

\begin{tabular}{|c|c|}
\hline A R T I C L E I N F O & A B S T R A C T \\
\hline $\begin{array}{l}\text { Keywords: } \\
\text { Antimicrobial } \\
\text { Phytochemical } \\
\text { Coconut } \\
\text { Shell } \\
\text { Time }\end{array}$ & $\begin{array}{l}\text { Coconut shell extract contains phytochemical compounds tannins, saponins and steroids which } \\
\text { are thought to act as antimicrobial compounds. This makes coconut shell extract has great potential } \\
\text { as a natural preservative, one of which is the natural preservative coconut sap. This study aims to } \\
\text { know the effect of coconut shell type, extraction time, extraction temperature and the combination } \\
\text { of the three treatments on the antimicrobial activity and phytochemical extracts produced. This } \\
\text { study using a Randomized Block Design (RBD). The factors tested were coconut shell type } \\
\text { consisting of: fresh old coconut shell; dry old coconut shell; fresh young coconut shell; dry young } \\
\text { coconut shell; length of extraction time consisting of: } 3 \text { and } 5 \text { hours' extraction time, and } \\
\text { extraction temperature consisting of: } 28^{\circ} \mathrm{C} \text { and } 70^{\circ} \mathrm{C} \text {. The variables observed in this study include } \\
\text { microbiological and phytochemical variables. The results showed that all type of coconut shell } \\
\text { extract contains phytochemical compounds such as tannin, saponins, and some samples contain } \\
\text { steroid compounds and had the ability of antimicrobial activity, especially in the bacterium } \\
\text { A.aceti. The combination of a dry old shell with an extraction time of } 3 \text { hours and extraction } \\
\text { temperature of } 28^{\circ} \mathrm{C} \text { has the highest antimicrobial activity against A.aceti bacteria with inhibition } \\
\text { zone diameter of } 13.25 \text { mm, positive containing phytochemical compounds tannins, saponins and } \\
\text { steroids and contains total phenol levels of } 18.67 \text { mg/ } 100 \mathrm{~g} \text {. }\end{array}$ \\
\hline
\end{tabular}

mazaya.gebi@gmail.com (iD) https://orcid.org/0000-0001-6581-605X

triyantosuwarjo@gmail.com (iD) https://orcid.org/0000-0002-9980-1451

${ }^{\mathbf{b}} \otimes$ karseno@unsoed.ac.id (iD) https://orcid.org/0000-0002-6670-1198

(c) (1) () Th This work is licensed under Creative Commons Attribution 4.0 International License

\section{Introduction}

The main components of coconut by-products consist of coir and shell (Sari and Pujiati, 2018). Previously, a byproduct of coconut fruit that had been used as a natural preservative for sap was coir. Coconut coir contains tannin compounds that can inhibit the antimicrobial activity in the palm sap by binding to enzymes and proteins produced from microbes so that the microbes become inactive (Rindengan et al., 2006). However, there are no studies that examine the ability of coconut shell antimicrobial activity associated with the process of preserving coconut sap.

Coconut shell waste so far has been widely used as raw material for activated charcoal and liquid smoke because of its excellent antimicrobial activity ability as a natural preservative (Sasongko et al., 2014). However, the literature regarding antimicrobial properties and natural preservatives in coconut shells without pyrolysis or carbonation processes is still very limited even though Indonesia is one of the largest coconut producing regions.

Literature studies that have proven the existence of antimicrobial activity in coconut shells have previously been carried out in India by Prakasah et al. (2018). His research proves the existence of antimicrobial activity in coconut shell extracts against Escherichia coli, Listeria monocytogenes and Salmonella enterica bacteria tested on preserving papaya fruit. Research on other commodities by Haryati et al. (2015), revealed that the oil palm shell extract has been clinically tested to be antibacterial, even though the dose used is quite high. Palm shell extract is effective as a bacteriostatic against Staphylococcus aureus and Escherichia coli at a concentration of $6 \%$. The concentration of palm shell extracts $14 \%$ is effective as bactericidal against Staphylococcus aureus and 12\% concentration of Escherichia coli. Palm shells are thought to contain triterpenoid and flavonoid compounds that act as antibacterial substances. Based on several studies above shows that there is potential in the coconut shell as an antimicrobial source because of the content of secondary metabolites that can be used as natural preservatives.

To get active compounds or secondary metabolites from an ingredient can be carried out by the extraction process. One of the most widely used extraction methods is continuous maceration. The continuous maceration 
method was chosen because this method can answer the weaknesses of the usual maceration method, namely the relatively long extraction time becomes shorter because of the constant motion that results in better contact between the solvent and the sample when compared to the usual maceration method (Pehlivan and Sevindik, 2018).

Things that need to be considered when the process of extracting a material is one of them is the time of extraction. The longer the extraction time, the higher the specific gravity of the extract and the percent yield obtained (Febrina et al., 2015). Besides the extraction time, the temperature is very important in extraction. In principle, the extraction process is strongly influenced by temperature. Extraction temperature can help in accelerating the extraction process and the higher the temperature used, the higher the extract obtained. But on the other hand, the temperature used must also be adjusted to the nature of the compound to be extracted. It is feared that the use of high temperatures can damage some active components that cannot withstand high temperatures. Although in some cases, extracted materials with varying degrees of temperature may not necessarily have different effects on their antimicrobial properties (Pambayun et al., 2007).

The purpose of this study was to determine the effect of coconut shell type, extraction time, extraction temperature and the combination of the three treatments of the antimicrobial activity and phytochemical extracts produced.

\section{Materials and Methods}

The materials needed are young and old coconut shells were obtained from market in Purwokerto, Indonesia), PCA (Plate Count Agar) and PGYA (Peptone Glucose Yeast Extract Agar), sodium carbonate $\left(\mathrm{Na}_{2} \mathrm{CO}_{3}\right)$, tannic acid were obtained from Sigma-Aldrich, S.cerevisiae yeast and A.aceti bacteria (Gadjah Mada University, Indonesia), indigenous microbes of coconut sap from coconut sugar farmers, distilled water, methanol, hydrochloric acid ( $\mathrm{HCl})$, Folin-Ciocalteu reagents, acid salt solution, kaolin powder, $\mathrm{KMnO}_{4}$, lead $\mathrm{IV}$ acetate $\left(\mathrm{Pb}(\mathrm{OAc})_{4}\right)$ anhydrous acetic acid $\left(\mathrm{C}_{4} \mathrm{H}_{6} \mathrm{O}_{3}\right)$, sulfuric acid $\left(\mathrm{H}_{2} \mathrm{SO}_{4}\right)$, iron (III) chloride $\left.\left(\mathrm{Pb}(\mathrm{OAc})_{4}\right) \mathrm{FeCl}_{3}\right)$, olive oil, Mayer reagent, mercury (II) chlorine $\left(\mathrm{HgCl}_{2}\right)$, potassium iodide (KI) Burchard reagent and chloroform were all obtained from Merck. Tools used include cabinet dryers (CFD 900), filter paper, dark-coloured glass bottles, Petri dishes (Pyrex), paper discs (Oxoid), measuring cups (Pyrex), measuring flask (Pyrex), Erlenmeyer (Pyrex), glass baker (Pyrex), test tube (Pyrex), micropipette (Gilson), measuring pipette (Herma), shaking waterbath (Stuart WW-12152-02), stove, vortex (Boeco Germany V2H), autoclave (All American 1925X), laminar airflow bench with UV light (KEL-HCB13), incubator (Memmert UNB400), bunsen, ose needle, calipers (Silverline 675037), UV-Vis spectrophotometer (Shimandzu 1800), fillers, analytical scales (AND GR-30), digital scales (Ohauss SJX1502) and spatulas.

Coconut shell is cleaned of dirt and then washed with clean running water. Diminishing the size of the particle size $1-2 \mathrm{~cm}$ and then dried in a cabinet dryer for $1 \times 24$ hours for dry material. For fresh ingredients not through the drying process.
The four types of coconut shells both old and young and which have been dried and fresh are weighed as much as 30 grams each, and dissolved with distilled water to a volume of $100 \mathrm{~mL}$ in the erlenmeyer tube. The extraction process uses a continuous maceration method with a waterbath shaker at $120 \mathrm{rpm}$ with 3 and 5 hours extraction time and $28^{\circ} \mathrm{C}$ and $70^{\circ} \mathrm{C}$ extraction temperature. The extraction results were filtered with filter paper, then each extract was tested for antimicrobial activity and phytochemical compound. Antimicrobial activity using microbes found in coconut sap including S.cerevisiae and A.aceti. Antimicrobial activity of the diffusion method (Ministry of Health, Republic of Indonesia, 1988); and phytochemicals including analysis of total phenols (Yun et al., 2017); tannins (Yadav et al., 2014); flavonoids (Ministry of Health, Republic of Indonesia, 1989); alkaloids (Ministry of Health, Republic of Indonesia, 1989); saponins (Yadav et al., 2014); triterpenoids (Ministry of Health, Republic of Indonesia, 1989) and steroids (Yadav et al., 2014).

\section{Antimicrobial Activity (Diffusion method)}

Inhibition testing of coconut shell material can be seen from the clear zone or clear zone formed on the surface of the media. Inhibition zone diameter measurements were carried out on three types of culture, namely mixed culture found in damaged coconut sap (left to stand at room temperature for 4 hours), yeast culture of S.cerevisiae and A.aceti bacteria. The use of S.cerevisiae yeast culture and A.aceti bacteria is based on the type of microbe that grows most on the palm sap (Sasmita et al., 2018). Microbial culture was incubated on PCA (Plate Count Agar) solid media, while the media used for S.cerevisiae and A.aceti were PGYA (Peptone Glucose Yeast Extract Agar). PCA (Plate Count Agar) was weighed as much as $2.5 \mathrm{~g}$ and dissolved with $100 \mathrm{~mL}$ of distilled water, put in an erlenmeyer while stirring until homogeneous, while the PGYA media used consisted of $0.75 \mathrm{~g}$ peptons; $2 \mathrm{~g}$ glucose; $0.45 \mathrm{~g}$ of yeast extract and $1 \%$ agar in $100 \mathrm{~mL}$ of distilled water. PCA and PGYA media were sterilized using an autoclave at $121^{\circ} \mathrm{C}$ at a pressure of 1 atm for 15 minutes.

Test tubes containing PCA and PGYA are sterile prepared, for test tubes containing PCA, microbes from damaged sap are added as much as 100 microliters, then divortex. Test tubes containing PGYA were added $100 \mu \mathrm{L}$ S.cerevisiae and A.aceti, respectively. S.cerevisiae and A.aceti bacteria were previously recultured from solid media to tilt to PGYA liquid media that had been incubated for 24 hours. The mixture of media and microbes that have been vortexed is poured into a petri dish, then the disc paper is dropped to $50 \mu \mathrm{L}$ each of the extract material with a concentration of $30 \%$ and wait for the extract to seep into the paper disc. Next, the disc paper is placed on the surface of the media that has compacted. Inhibition zone observations were made after incubation at $37^{\circ} \mathrm{C}$ for 18 hours by measuring the diameter of the clear zone using calipers and the diameter of the clear zone was recorded as the amount of microbial inhibition and were repeated twice. 
Total Phenols (Yun et al., 2017)

$0.4 \mathrm{~mL}$ of the sample solution was added to $1.5 \mathrm{~mL}$ of the Folin-Ciocalteu reagent $(10 \% \mathrm{v} / \mathrm{v})$. The sample was incubated for 5 minutes. Then mixed with $1.5 \mathrm{~mL}$ of sodium carbonate $\left(\mathrm{Na}_{2} \mathrm{CO}_{3}\right) 7,5 \%(\mathrm{w} / \mathrm{v})$ solution. After 90 minutes incubated at room temperature and dark conditions the absorbance was measured at a wavelength of $765 \mathrm{~nm}$. Tannic acid is used as a standard.

\section{Taninn-Braymer's Test (Yadav et al., 2014)}

As much as $2 \mathrm{~mL}$ of sample extract was put into a test tube, then the sample was added $2 \mathrm{~mL}$ of distilled water and added 4 drops of iron III chloride $\left(\mathrm{FeCl}_{3}\right) 5 \%$. If a bluish green precipitate is formed, the positive sample contains tannin compounds.

\section{Flavonoids (Ministry of Health, Republic of Indonesia, 1989) \\ As much as $1 \mathrm{~mL}$ of sample extract added $1 \mathrm{~mL}$ of lead IV acetate $(\mathrm{Pb}(\mathrm{Oac}) 410 \%$. Positive flavonoids if there is a red, yellow/orange color in the solution.}

Alkaloids-Mayer's Test (RI Ministry of Health, 1989)

A total of $2 \mathrm{~mL}$ of sample extract was prepared in a test tube then added 5 drops of Mayer reagent. If a white or yellow lumpy sediment is formed the sample contains an alkaloid. The making of the Mayer reagent $2.266 \mathrm{~g}$ of mercury (II) chloride $\left(\mathrm{HgCl}_{2}\right)$ dissolved in distilled water to $100 \mathrm{~mL}$. In another container, $50 \mathrm{~g}$ of potassium iodide (KI) is dissolved in $100 \mathrm{~mL}$ of distilled water. Then $60 \mathrm{~mL}$ of solution I is mixed with $10 \mathrm{~mL}$ of solution II and add distilled water to $100 \mathrm{~mL}$.

\section{Saponin-Foam Test (Yadav et al., 2014)}

As much as $2 \mathrm{~mL}$ of sample extract was put into a test tube, added $2 \mathrm{~mL}$ of distilled water and heated for 10 minutes. Then the sample is cooled and shaken for 10 seconds, if foam formed as high as $1-10 \mathrm{~cm}$, stable for 10 minutes and not lost with the addition of 1 drop of $\mathrm{HCl} 2$ $\mathrm{N}$ indicates the presence of saponins. Preparation of $2 \mathrm{~N}$ $\mathrm{HCl}$ reagents, namely $17 \mathrm{~mL}$ of concentrated $\mathrm{HCl}$, diluted with distilled water to $100 \mathrm{~mL}$.

Checking the saponin content can also be tested by adding olive oil. A total of $2 \mathrm{~mL}$ of sample extract was prepared in a test tube, then added 5 drops of olive oil and shaken. Positive saponins are characterized by the formation of an emulsion between the sample and olive oil.

Triterpenoid-Lieberman-Burchard (RI Ministry of Health, 1989)

As much as $2 \mathrm{~mL}$ of sample extracts were added $2 \mathrm{~mL}$ of anhydrous acetic acid and 2 to 3 drops of concentrated sulfuric acid (Liebermann-Burchard reagent). If a positive purple or red sample is formed containing triterpenoids (Harbone, 1987). The making of a Burchard reagent is 10 drops of anhydrous acetic acid mixed with 1 drop of concentrated sulfuric acid.

\section{Steroid-Salkowski Test (Yadav et al., 2014)}

As much as $2 \mathrm{~mL}$ of sample extract was put into a test tube, then added $2 \mathrm{~mL}$ of chloroform and added $2 \mathrm{~mL}$ of concentrated sulfuric acid. If there is a brownish red ring between the layers of solution, the positive sample contains a steroid compound.

\section{Statistical Analysis}

The experiment was done as randomized block design were repeated twice. Two-wayanalysis of variance (ANOVA) was done with all the data to confirm the variability of data and validity of results and Duncan's Multiple Range Test (DMRT) was performed to determine the significant difference between treatments. Statistically difference was set at $\mathrm{P}<0.05$, while qualitative data is presented descriptively.

\section{Results and Discussion}

\section{Antimicrobial Activity}

Based on the antimicrobial activity data of coconut shell extract illustrated by the diameter of inhibitory zones against the three types of microbes above (Table 1) of the three types of microbes, S.cerevisiae has the highest resistance to coconut shell extract, then microbes from indigenous microbes of broken coconut sap and A.aceti which has the strength the weakest. This is possible because half the population of microbes in the sap is A.aceti and S.cerevisiae so that the area of the inhibition zone is in the middle position between the yeast S.cerevisiae and the bacterium A.aceti. It can be described that those who can survive are from the yeast population of S.cerevisiae and those who are unable to survive are from the population of the bacterium A.aceti.

A.aceti bacteria had the lowest resistance to the antimicrobial properties of the coconut shell extract with an average inhibitory strength of 8-13.25 mm (Figure 1). This can be caused by A.aceti, which is a group of gramnegative bacteria. The peptidoglycan layer that makes up the bacterial cell wall with the cell wall substance, theatric acid, has a thinner thickness than gram-positive bacteria, so that the cell wall of gram-negative bacteria are more susceptible to damage. Peptidoglycan is a component used to maintain cell integrity. Thinner peptidoglycan layer or little or no content of the teichoic acid that makes up the cell wall of both gram-negative and gram-negative bacteria cause the cell walls to be more easily damaged when given antibacterial (Radji, 2011).

Besides that, the old coconut shell has a slightly higher $\mathrm{pH}$ compared to the young coconut shell which is 6.55 in a dry old coconut shell and 6.79 in a fresh old coconut shell. Meanwhile, the optimum $\mathrm{pH}$ for the growth of the bacterium A.aceti is 5.4-6.3. The $\mathrm{pH}$ of the old coconut shell extract which exceeds the optimum condition of the growth of the bacterium A.aceti, which means that the extract of the old coconut shell can help weaken the growth or even denaturation the bacteria (Surtiyani, 2015).

Based on the antimicrobial activity data of coconut shell extract which is illustrated by the diameter of inhibitory zones against the three types of microbes above (Table 1). Inhibition zone diameter of coconut shell extract against yeast S.cerevisiae is the smallest even some treatments do not produce inhibitory zones. The small inhibitory zone size indicates low antimicrobial extract activity, while the large diameter inhibitory zone size indicates high antimicrobial extract activity (Pelczar and Chan, 2005).

This can be caused by the yeast S.cerevisiae has strong fermentative properties which can oxidize sugar to carbon dioxide and water, have biochemical stability 
(characteristic shape), the ability to scatter (spread) quickly in water, the ability to fight autoxic and normal temperatures and have biochemical stability (characteristic shape), the ability to spread quickly in water, the ability to fight autoxis and normal temperatures and the ability to produce well in a propagation medium (Periadnadi et al., 2018). Besides, S.cerevisiae is more tolerant of acidic environments, with $\mathrm{pH}$ ranging between 3.5 and 4.5 .

Rita (2010), stated that the antimicrobial strength provisions of material are if the inhibition area of $20 \mathrm{~mm}$ or included in the category of antimicrobials is very strong, a resistance area of 10-20 mm means strong, 5-10 mm means medium and a barrier area of $5 \mathrm{~mm}$ or less means weak. Coconut shell extract at a concentration of $30 \%$ has inhibitory strength with moderate classification in the bacterium A.aceti and has inhibitory strength with a weak classification of the types of microbes found in indigenous microbes of coconut sap (left to stand for 4 hours) or in yeast S.cerevisiae.

\section{Total Phenol Extract}

Determination of total phenolic content in coconut shell extracts was determined using the Folin-Ciocalteu method based on the ability of phenolic compounds to react with the Folin-Ciocalteu reagent containing phosphomolybdatephosphotungstic acid to form a blue complex. The blue colour formed is equivalent to the concentration of phenolate ions formed. Phenolate ions will be formed if a phenolic compound is in an alkaline atmosphere. Phenolic ions formed from the formation of a phenol compound will reduce heterophilic acid from phosphomolybdatephosphotungstic acid, so that the blue colour resulting from the reduction of heteropoly acid will experience an increase in color intensity (Yun et al., 2017).

The results showed that the extraction temperature significantly affected the total levels of the phenol shell extract. Figure 2 shows an increase in total phenol with increasing extraction temperature. At $70^{\circ} \mathrm{C}$ a total phenol value of $28.31 \mathrm{mg} / 100 \mathrm{~g}$ was obtained, while at $28^{\circ} \mathrm{C}$ a much lower value was obtained, $18.85 \mathrm{mg} / 100 \mathrm{~g}$. This is presumably because the high temperature will cause the solubility of phenolic compounds such as tannins in the great solvent, which is characterized by higher colour, solubility or higher extraction temperatures, the resulting coconut shell extract colour will be darker.

Different letters indicate significantly different valuesat a particular treatment (DMRT, $\mathrm{P}<0.05)$.

Phenolic compounds are compounds that tend to dissolve easily in water because they contain hydroxyl groups that can increase water solubility (Sevindik et al., 2017). By increasing the temperature, the diffusion that occurs is also getting bigger, so the extraction process will also run faster.
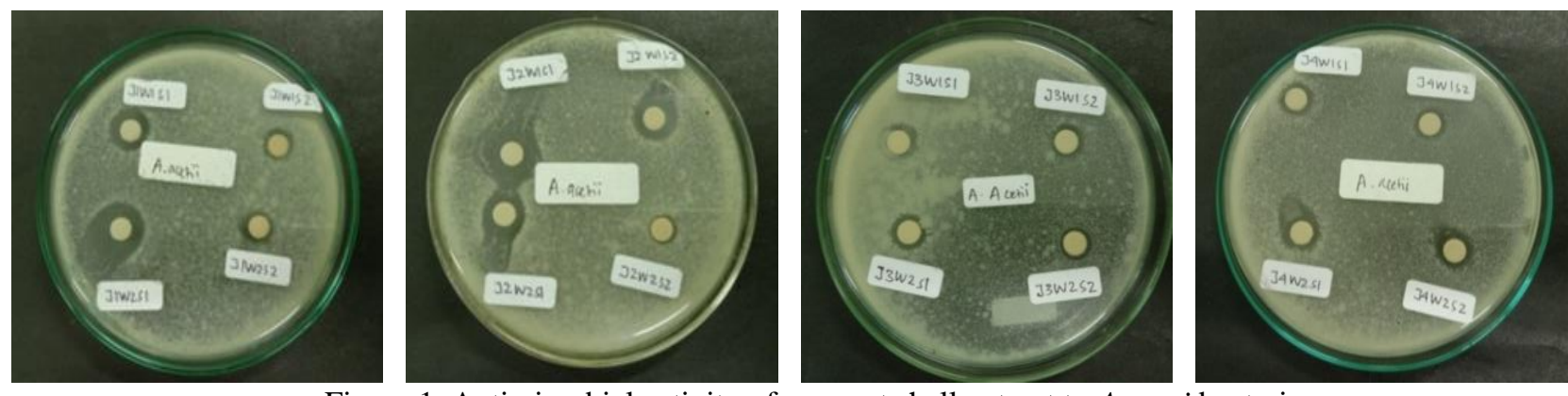

Figure 1. Antimicrobial activity of coconut shell extract to A.aceti bacteria

Table 1 . Results of the antimicrobial activity of coconut shell extract

\begin{tabular}{|c|c|c|c|c|c|}
\hline \multirow{2}{*}{$\begin{array}{l}\text { Coconut shell } \\
\text { type }\end{array}$} & \multirow{2}{*}{$\begin{array}{l}\text { Length of } \\
\text { extraction time } \\
\text { (hours) }\end{array}$} & \multirow{2}{*}{$\begin{array}{c}\text { Extraction } \\
\text { temperature }\left({ }^{\circ} \mathrm{C}\right)\end{array}$} & \multicolumn{3}{|c|}{ Diameter $(\mathrm{mm})$} \\
\hline & & & $\begin{array}{l}\text { *Indigenous } \\
\text { microbes }\end{array}$ & A. aceti & S. cerevisiae \\
\hline \multirow{4}{*}{ Fresh old shell } & \multirow{2}{*}{3} & 28 & $8.25 \pm 1.06$ & $10 \pm 2.83$ & $6 \pm 0$ \\
\hline & & 70 & $7.5 \pm 0.71$ & $9 \pm 0$ & $6 \pm 0$ \\
\hline & \multirow{2}{*}{5} & 28 & $8.50 \pm 0.71$ & $12.25 \pm 6.01$ & $6 \pm 0$ \\
\hline & & 70 & $8.25 \pm 1.06$ & $9.25 \pm 0.35$ & $6.5 \pm 0.71$ \\
\hline \multirow{4}{*}{ Dry old shell } & \multirow{2}{*}{3} & 28 & $7.5 \pm 0$ & $13.25 \pm 7.07$ & $7 \pm 1.41$ \\
\hline & & 70 & $7.5 \pm 0.71$ & $11.50 \pm 4.95$ & $6.5 \pm 0.71$ \\
\hline & \multirow{2}{*}{5} & 28 & $8.25 \pm 0.35$ & $10.50 \pm 2.83$ & $8 \pm 0$ \\
\hline & & 70 & $7.25 \pm 0.35$ & $8 \pm 0.71$ & $6.5 \pm 0$ \\
\hline \multirow{4}{*}{ Fresh young shell } & \multirow{2}{*}{3} & 28 & $7.50 \pm 0.71$ & $9.5 \pm 0.71$ & $6.5 \pm 0.71$ \\
\hline & & 70 & $7.87 \pm 0.17$ & $9 \pm 0$ & $6 \pm 0$ \\
\hline & \multirow{2}{*}{5} & 28 & $8.00 \pm 0.71$ & $8.75 \pm 1.06$ & $7.5 \pm 2.12$ \\
\hline & & 70 & $7.25 \pm 1.06$ & $9 \pm 0$ & $6 \pm 0$ \\
\hline \multirow{4}{*}{ Dry young shell } & \multirow{2}{*}{3} & 28 & $7.75 \pm 1.06$ & $8.5 \pm 2.12$ & $6 \pm 0$ \\
\hline & & 70 & $7.75 \pm 0.35$ & $8.25 \pm 0.35$ & $6.5 \pm 0.71$ \\
\hline & \multirow{2}{*}{5} & 28 & $7.75 \pm 1.06$ & $9.5 \pm 0.71$ & $7.5 \pm 2.12$ \\
\hline & & 70 & 7.750 .35 & $8.5 \pm 2.12$ & $6 \pm 0$ \\
\hline
\end{tabular}

$\overline{\text { Note: Paper disc diameter }}=6 \mathrm{~mm}$, *Indigenous microbes of broken coconut sap. 


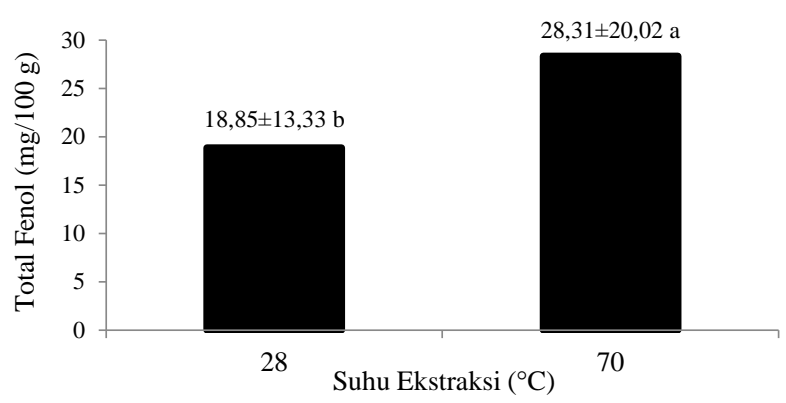

Figure 2. Effect of extraction temperature on total phenolic content in the coconut shell extracts

Table 2. Results of the total phenol coconut shell extract

\begin{tabular}{c|ll}
\hline No. & \multicolumn{1}{|c}{ Samples } & \multicolumn{1}{|c}{$\begin{array}{c}\text { Total phenols } \\
(\mathrm{mg} / 100 \mathrm{~g})\end{array}$} \\
\hline 1. & Fresh old shell; $3 \mathrm{hr} ; 28^{\circ} \mathrm{C}$ & $22.36 \pm 0$ \\
2. & Fresh old shell; 3hr;70 $\mathrm{C}$ & $34.62 \pm 21.17$ \\
3. & Fresh old shell; 5hr; $28^{\circ} \mathrm{C}$ & $23.48 \pm 12.59$ \\
4. & Fresh old shell; $5 \mathrm{hr} ; 70^{\circ} \mathrm{C}$ & $27.98+10.21$ \\
5. & Dry old shell; $3 \mathrm{hr} ; 28^{\circ} \mathrm{C}$ & $18.67 \pm 2.78$ \\
6. & Dry old shell; $3 \mathrm{hr} ; 70^{\circ} \mathrm{C}$ & $25.67 \pm 4.38$ \\
7. & Dry old shell; $5 \mathrm{hr} ; 28^{\circ} \mathrm{C}$ & $17.34 \pm 1.36$ \\
8. & Dry old shell; $5 \mathrm{hr} ; 70^{\circ} \mathrm{C}$ & $27.33 \pm 0.86$ \\
9. & Fresh young shell; $3 \mathrm{hr} ; 28^{\circ} \mathrm{C}$ & $7.67 \pm 0.89$ \\
10. & Fresh young shell; $3 \mathrm{hr} ; 70^{\circ} \mathrm{C}$ & $20.08 \pm 5.67$ \\
11. & Fresh young shell; $5 \mathrm{hr} ; 28^{\circ} \mathrm{C}$ & $22.11 \pm 18.15$ \\
12. & Fresh young shell; $5 \mathrm{hr} ; 70^{\circ} \mathrm{C}$ & $31.88 \pm 18.80$ \\
13. & Dry young shell; $3 \mathrm{hr} ; 28^{\circ} \mathrm{C}$ & $24.76 \pm 5.34$ \\
14. & Dry young shell; $3 \mathrm{hr} ; 70^{\circ} \mathrm{C}$ & $29.26 \pm 10.86$ \\
15. & Dry young shell; $5 \mathrm{hr} ; 28^{\circ} \mathrm{C}$ & $14.42 \pm 11.05$ \\
16. & Dry young shell; $5 \mathrm{hr} ; 70^{\circ} \mathrm{C}$ & $29.65 \pm 10.65$ \\
\hline
\end{tabular}

In the study of Amin and Yuliana (2016) in a color stability test on secang wood plants stated that the higher the heating temperature, the colour of the secang wood extract getting older or darker. From each colour treatment of secang wood extract has a different colour that is secang wood extract at a temperature of $100^{\circ} \mathrm{C}$ tends to be older than the colour of the secang wood extract at a temperature of $90^{\circ} \mathrm{C}$ and a temperature of $25^{\circ} \mathrm{C}$, as well as at a temperature of $90^{\circ} \mathrm{C}$ which has an older extract colour compared with a temperature of $25^{\circ} \mathrm{C}$.

This is also in line with research conducted by Puspitasari and Desrita (2019), which proves that tannin compounds, which are one of the phenol compounds in mangrove leaves of type E. agallocha, still exist when phytochemical testing is carried out even though it has been through the boiling process with a temperature of 85 $90^{\circ} \mathrm{C}$ for 15 minutes. However, increasing the operating temperature also needs to be considered, because temperatures that are too high can cause damage to the material being processed (Ibrahim et al., 2014).

Phenol contained in coconut shell extract is one composition that contains antimicrobial substances. The existence of a clear zone when testing antimicrobial activity The way phenol works is by poisoning the protoplasm, damaging and penetrating the cell wall, and depositing microbial cell proteins. The phenol component also denaturation the enzymes responsible for germination of spores or those responsible for the amino acids involved in the germination process, increase the permeability of cytoplasmic membranes, increase the use of intracellular components and cytoplasmic coagulation so as to increase lysis cells (Mulyatni et al., 2016). However, not all classes have functions as antimicrobial compounds. At the use of $70^{\circ} \mathrm{C}$ extraction temperature shows high phenol levels but the antimicrobial activity against yeast S.cerevisiae is lower than the use of $28^{\circ} \mathrm{C}$ temperature. It is discussed that not all phenol compounds extracted in air solvents are phenol compounds which have antimicrobial properties. For example, lignin is mostly contained in coconut shells that are included in the phenolic group which do not function as antimicrobials that are not yet understood (Matheos, 2014).

\section{Phytochemical Compounds}

Phytochemicals are chemical compounds produced by plants which can also be interpreted as secondary metabolites. Phytochemicals are non-nutrient chemical compounds produced by cells from plants. Phytochemical testing is a way to identify bioactives that have not been visible through a test or examination that can quickly separate natural materials that have certain phytochemical contents from natural materials that do not have certain phytochemical contents. Phytochemical testing is also a preliminary stage in a phytochemical study that aims to provide an overview of the class of compounds contained in the plant under study. The phytochemical test method is carried out by looking at the colour testing reaction using a colour reagent (Minarno, 2015).

To find out what groups of compounds contained in coconut shell extract, phytochemical compounds were analysed. The results obtained (Table 3.) show that coconut shell extract treated with shell type, length of time and extraction temperature contained a group of tannin, saponin and steroid compounds, but did not contain alkaloid, triterpenoid and flavonoid compounds. According to Artini et al. (2013), different environmental conditions, such as the location of growth can cause differences in the number and type of secondary metabolites contained in a commodity that grows in an area with other regions.

Based on the results of the qualitative phytochemical analysis, coconut shell extracts contain tannins, saponins, and steroids. These three compounds are thought to play a role as an antimicrobial source in coconut shell extracts.

\section{Taninn}

The presence of tannin compounds can be seen from the color changes that occur when adding $1 \% \quad \mathrm{FeCl} 3$ solution blackish green. Addition of $1 \% \mathrm{FeCl}_{3}$ solution is estimated that this solution reacts with one of the hydroxyl groups present in tannin compounds. $\mathrm{FeCl}_{3}$ reagents are widely used to identify phenol compounds including tannins (Artini et al., 2013).

Table 2 shows that all positive coconut shell extract treatments contain tannin compounds. In the treatment with high temperatures $70^{\circ} \mathrm{C}$ produces a darker shell extract colour compared with the use of temperatures $28^{\circ} \mathrm{C}$, which can be interpreted to contain tannin compounds at the use of high extraction temperatures more than with low extraction temperatures. The use of high temperatures in extraction will cause a stronger reaction because the energy produced is higher, the insoluble substances will dissolve. These results are in line with the research of Fahriya and Shofi (2011), which states that at high temperatures an increase in tannin levels is indicated by the occurrence of a darker colour change with increasing extraction temperatures. 
Table 3. Phytochemical compounds of coconut shell extract

\begin{tabular}{|c|c|c|c|c|c|c|}
\hline Samples & Flavonoid & Alkaloid & Taninn & Saponin & Triterpenoid & Steroid \\
\hline Fresh old shell; $3 \mathrm{hr} ; 28^{\circ} \mathrm{C}$ & - & - & + & + & - & ++ \\
\hline Fresh old shell; $3 \mathrm{hr} ; 70^{\circ} \mathrm{C}$ & - & - & ++ & ++ & - & ++ \\
\hline Fresh old shell; $5 \mathrm{hr} ; 28^{\circ} \mathrm{C}$ & - & - & + & + & - & - \\
\hline Fresh old shell; $5 \mathrm{hr} ; 70^{\circ} \mathrm{C}$ & - & - & ++ & ++ & - & - \\
\hline Dry old shell; $3 \mathrm{hr} ; 28^{\circ} \mathrm{C}$ & - & - & + & + & - & ++ \\
\hline Dry old shell; $3 \mathrm{hr} ; 70^{\circ} \mathrm{C}$ & - & - & ++ & ++ & - & ++ \\
\hline Dry old shell; $5 \mathrm{hr} ; 28^{\circ} \mathrm{C}$ & - & - & + & + & - & - \\
\hline Dry old shell; $5 \mathrm{hr} ; 70^{\circ} \mathrm{C}$ & - & - & + & ++ & - & - \\
\hline Fresh young shell; $3 \mathrm{hr} ; 28^{\circ} \mathrm{C}$ & - & - & + & + & - & + \\
\hline Fresh young shell; $3 \mathrm{hr} ; 70^{\circ} \mathrm{C}$ & - & - & + & ++ & - & - \\
\hline Fresh young shell; $5 \mathrm{hr} ; 28^{\circ} \mathrm{C}$ & - & - & + & + & - & - \\
\hline Fresh young shell; $5 \mathrm{hr} ; 70^{\circ} \mathrm{C}$ & - & - & ++ & ++ & - & ++ \\
\hline Dry young shell; $3 \mathrm{hr} ; 28^{\circ} \mathrm{C}$ & - & - & + & + & - & - \\
\hline Dry young shell; $3 \mathrm{hr} ; 70^{\circ} \mathrm{C}$ & - & - & ++ & ++ & - & - \\
\hline Dry young shell; $5 \mathrm{hr} ; 28^{\circ} \mathrm{C}$ & - & - & + & + & - & - \\
\hline Dry young shell; $5 \mathrm{hr} ; 70^{\circ} \mathrm{C}$ & - & - & ++ & ++ & - & - \\
\hline
\end{tabular}

Note: $(++)=$ Positive high content; $(+)=$ Positive low content; $(-)=$ negative.

The mechanism of action of tannin as an antimicrobial is related to the ability of tannins to inactivate adhesin microbial cells (molecules attached to host cells) found on the cell surface. Tannins that have targets on cell wall polypeptides will cause cell wall damage, because tannins are phenol compounds. On destruction of cell membranes, $\mathrm{H}^{+}$ions from phenol compounds and their derivatives will attack the polar group (phosphate group) so that the phospholipid molecule will break down into glycerol, carboxylic acid and phosphoric acid. Tannin compounds can bind to enzymes produced by microbes so that microbes are not active. Tannins have axiomatic action and antiseptic properties (Rohaeni, 2016). According to Poeloengan and Praptiwi (2010), tannins at low concentrations can inhibit microbial growth, whereas at high concentrations, tannins work as antimicrobials by agglomerating microbial protoplasms, so that they form stable bonds with microbial proteins.

\section{Saponin}

Saponins are surface active compounds and are soapy, and can be detected based on their ability to form foam that is stable in water. According to Marlinda et al. (2012), compounds that have polar and nonpolar groups are surface active so that when saponins are shaken with water they can form micelles. In the micelle structure, the polar group faces outward while the non-polar group faces inward, this is what looks like foam. The emergence of foam or froth indicates the presence of glycosides which have the ability to form froth in water that is hydrolyzed into glucose and other compounds (Nugrahani et al., 2016).

Table 2 shows that all treatments of positive coconut shell extract contain saponin compounds. In the treatment with high temperature $70^{\circ} \mathrm{C}$ shows that the foam produced by shell extract is more than the use of temperature $28^{\circ} \mathrm{C}$, which can be interpreted as saponin compound content at the use of high extraction temperature more than with low extraction temperature. This is supported by research by Vongsangnak et al. (2004), which states that the heating process with a temperature of $50^{\circ} \mathrm{C}$ quantitatively produced higher levels of saponin from notoginseng that is $125 \mathrm{mg} / \mathrm{g}$ compared to without the heating process which is as much as $71 \mathrm{mg} / \mathrm{g}$.
The mechanism of action of saponins as an antibacterial is by downloading proteins. Because the surface active ingredient of saponin is similar to detergent, saponin can be used as an antibacterial where the surface tension of the bacterial cell wall will be reduced and the permeability of the bacterial membrane is damaged (Arabski et al., 2012). Bacterial survival will be disrupted due to damage to cell membranes. Then saponins will diffuse through the cytoplasmic membrane so that the stability of the membrane will be disrupted which causes the cytoplasm to leak and exit the cell resulting in cell death.

\section{Steroid}

Steroid is a lipid class derived from saturated compounds and is a secondary metabolic compound that is widely used as medicine. The mechanism of action of steroids as antimicrobials is by damaging the lipid membrane of microorganisms, so that the liposomes leak (Madduluri et al., 2013). Steroids are known to interact with phospholipid membranes, because they are permeable to lipophilic compounds causing decreased membrane integrity and impaired cell membrane morphology which results in cell lysis (Sudarmi et al., 2017).

Table 3 shows that not all sample treatments contain steroid phytochemical compounds. This can be caused by the steroid compounds that exist in young and old coconut shell extracts are very few. However, when viewed from the results of phytochemical tests, old coconut shells show more positive results on steroid tests than young coconut shells. According to Kristianti et al. (2008), basically steroids are non-polar compounds but, in nature, especially in steroid plants are in the form of glycosides (bound to sugar groups) which are more polar in nature. The undetectability of steroid compounds in some treatments may be caused by the water solvent being unable to attract steroid compounds in the coconut shell optimally even though some positive treatments contain steroid compounds. The influencing factor can occur due to the dipole moment of polar and semi-polar compounds which will induce non-polar molecules that do not have a dipole so that there will be an electrostatic force between the two. This force causes non-polar compounds to dissolve or be slightly soluble in both polar and non-polar solvents (Firdiyani et al., 2015). Commonly used solvents in the steroid extraction process are methanol, ethanol, acetone, ethyl acetate. 


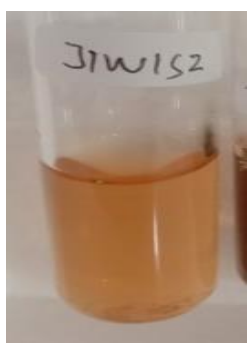

Extract before testing analysis

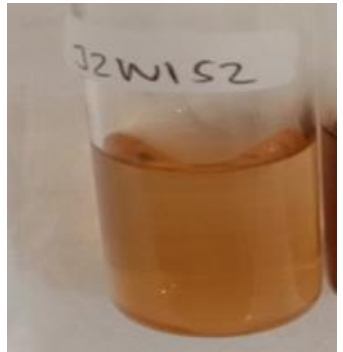

Extract before analysis

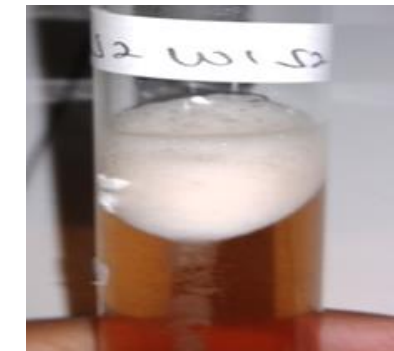

Extract after analysis
Figure 4. Results of coconut shell extract saponins analysis

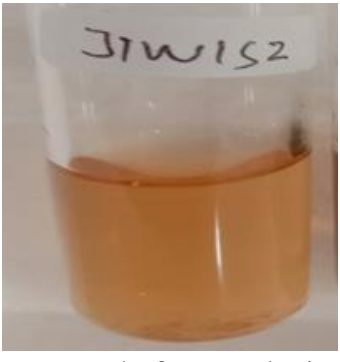

Extract before analysis

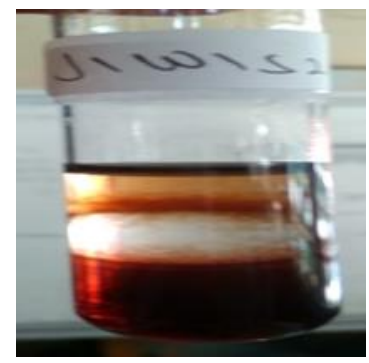

Extract after analysis
Figure 5. Results of the coconut shell extract steroid analysis

Type of shell is one of the factors that influence the content of phytochemical compounds. Based on the type of shell, the treatment of old coconut shell extract showed more positive steroid compounds compared to the extract of young coconut shell. This can be caused by the old shell having a more perfect level of maturity resulting in a high rate of photosynthesis, along with the rate of photosynthesis the secondary metabolites that are formed are also more numerous than the young coconut shell. According to Tehubijuluw et al. (2018), secondary metabolites of flavonoid compounds have higher levels in old seagrass leaves compared to half-old seagrass leaves and young leaves. In research conducted by Wulandari et al. (2018), also showed tannin, phenol and flavonoid secondary metabolites in old coconut coir have higher levels than half-old and young coir.

\section{Conclusion}

Coconut shell extract with varying levels of aging has the ability of antimicrobial activity, especially in the bacterium A.aceti and is classified as medium inhibitory criteria. The extraction time and temperature do not affect antimicrobial activity.

All type of coconut shell extract contains phytochemical compounds such as tannin, saponins, and some samples contain steroid compounds and had the ability of antimicrobial activity, especially in the bacterium A.aceti. The combination of a dry old shell with an extraction time of 3 hours and extraction temperature of $28^{\circ} \mathrm{C}$ has the highest antimicrobial activity against A.aceti bacteria with inhibition zone diameter of $13,25 \mathrm{~mm}$, positive containing phytochemical compounds tannins, saponins and steroids and contains total phenol levels of $18,67 \mathrm{mg} / 100 \mathrm{~g}$.

\section{References}

Amin S, Yuliana A. 2016. Analisis dan Uji Kestabilan Zat Warna Kayu Secang (Caesalpinia sappan L.) Menggunakan Spektrofotometer Uv- Visibledan Inframerah. Jurnal Kesehatan Bakti Tunas Husada: Jurnal Ilmu-Ilmu Keperawatan, Analis Kesehatan dan Farmasi, 15(1): 56-63.

Arabski M. Wegierek-Ciuk A, Czerwonka G, Lankoff A, Kaca W. 2012. Effect of Saponin Againts Clinical Escherichia coli Strains and Eukaryotic Cell Lines. Journal of Biomedicine and Biotechnology, 20(12): 1-6.

Artini PEUD, Astuti KW, Warditiani NK. 2013. Uji Fitokimia Ekstrak Etil Asetat Rimpang Bangle (Zingiber purpureum Roxb). Jurnal Farmasi Udayana, 2(4): 6-12.

Fahriya PS, Shofi MS. 2011. Ekstraksi Zat Aktif Antimikroba dari Tanaman Yodium (Jatropha multifida Linn) Sebagai Bahan Baku Alternatif Antibiotik Alami. Skripsi. Jurusan Teknik Kimia. Universitas Diponegoro.

Febrina L, Rusli R, Muflihah F. 2015. Optimalisasi Ekstraksi dan Uji Metabolit Sekunder Tumbuhan Libo (Ficus variegate blume). Journal of Tropical Pharmacy and Chemistry, 3(2): 74-81.

Firdiyani F, Agustini TW, Ma'ruf WF. 2015. Ekstraksi Senyawa Bioaktif Sebagai Antioksidan Alami Spirulina platensis Segar Dengan Pelarut yang Berbeda. Jurnal Pengolahan Hasil Perikanan Indonesia, 18(1): 28-37.

Haryati S, Hamzah F, Restuhadi F. 2015. Uji Aktivitas Antibakteri Ekstrak Cangkang Kelapa Sawit (Elaeis Guineensis Jacq.,). Jurnal Online Mahasiswa Fakultas Pertanian Universitas Riau, 2(1): 1-10.

Ibrahim AM, Yunianta Y, Sriherfyna FH. 2014. Pengaruh Suhu dan Lama Waktu Ekstraksi Terhadap Sifat Kimia dan Fisik pada Pembuatan Minuman Sari Jahe Merah (Zingiber officinale var. Rubrum) Dengan Kombinasi Penambahan Madu Sebagai Pemanis. Jurnal Pangan dan Agroindustri, 3(2): 530-541.

Kristianti AN, Aminah NS, Tanjung M, Kurniadi B. 2008. Buku ajar fitokimia. Jurusan Kimia Laboratorium Kimia Organik Fakultas Matematika dan Ilmu Pengetahuan Alam. Universitas Airlangga.

Madduluri SRAO, Rao KB, Sitaram B. 2013. In Vitro Evaluation of Antibacterial Activity of Five Indigenous Plants Extract Against Five Bacterial Pathogens of Human. International Journal of Pharmacy and Pharmaceutical Sciences. 5(4): 679-684.

Marlinda M, Sangi MS, Wuntu AD. 2012. Analisis Senyawa Metabolit Sekunder dan Uji Toksisitas Ekstrak Etanol Biji Buah Alpukat (Persea americana Mill.). Jurnal Matematik dan Ilmu Pengetahuan Alam, 1(1): 24-28. doi: 10.35799/jm.1.1.2012.427

Matheos H. 2014. Aktivitas Antioksidan dari Ekstrak Daun Kayu Bulan (Pisonia alba). PHARMACON, 3(3):235-246.

Ministry of Health, Republic of Indonesia. 1988. Inventaris Obat Indonesia Jilid I. Badan Penelitian dan Pengembangan Kesehatan. Departemen Kesehatan Republik Indonesia. Jakarta. 
Ministry of Health, Republic of Indonesia. 1989. Acuan Sediaan Herbal. Jakarta: Departemen Kesehatan Republik Indonesia.

Minarno EB. 2015. Skrining Fitokimia dan Kandungan Total Flavanoid PadaBuah Carica pubescens Lenne dan K.Koch Di Kawasan Bromo, Cangar dan Dataran Tinggi Dieng. elHayah, 5(2): 73-82.

Mulyatni AS, Budiani A, Taniwiryono D. 2016. Aktivitas Antibakteri Ekstrak Kulit Buah Kakao (Theobroma cacao L.) Terhadap E.coli, B.subtilis dan S.aureus. E-Journal Menara Perkebunan, 80(2): 77-84.

Nugrahani R, Andayani Y, Hakim A. 2016. Skrining Fitokimia dari Ekstrak Buah Buncis (Phaseolus vulgaris L) dalam Sediaan Serbuk. Jurnal Penelitian Pendidikan Ilmu Pendidikan Alam. 2(1): doi : 10.29303 / jppipa.v2i1.38

Pambayun R, Gardjito M, Sudarmadji S, Kuswanto KR. 2007. Phenolic Content and Antibacterial Properties of Various Extracts of Gambir (Uncaria gambir Roxb). Indonesian Journal of Pharmacy, 18(3): 141-146.

Pehlivan M, Sevindik M. 2018. Antioxidant and Antimicrobial Activities of Salvia multicaulis. Turkish Journal of Agriculture-Food Science and Technology, 6(5): 628-631.

Pelczar MJ, dan Chan ECS. 2005. Dasar-Dasar Mikrobiologi. Jakarta.

Periadnadi P, Sari DK, Nurmiati N. 2018. Isolasi dan Keberdaan Khamir Potensial Pemfermantasi Nira Aren (Arenga pinnata Merr.) dari Dataran Rendah dan Dtaran Tinggi di Sumatera Barat. Bioeksperimen: Jurnal Penelitian Biologi, 4(1): 29-36.

Poeloengan M, Praptiwi P. 2010. Uji Aktivitas Antibakteri Ekstrak Kulit Buah Manggis (Garcinia mangostana Linn). Media Penelitian dan Pengembangan Kesehatan, 20(2): 6569.

Prakash A, Nithyanand P, Vadivel V. 2018. In Vitro Antibacterial Activity of Nut By-Products against Foodborne Pathogens and Their Application in Fresh-Cut Fruit Model. Journal of Food Science and Technology, 55(10): 4304-4310. doi: 10.1007/s13197-018-3373-X

Puspitasari D, Desrita D. 2019. The Influence of The Mangrove Leaves Infusion Excoecaria Agallocha Against Aeromonas hydrophila bacterial infection in Tilapia. Acta Aquatica: Aquatic Sciences Journal, 6(1): 41-45. doi: 10.29103/aa.v6i1.1064

Radji M. 2011. Mikrobiologi. Buku Kedokteran. ECG: Jakarta
Rindengan B, Karouw S, Pasang P. 2006. Pengaruh Sabut Kelapa Terhadap Kualitas Nira Aren dan Palm Wine. Jurnal Penelitian Tanaman Industri, 12(4): 166-171.

Rita W S. 2010. Isolasi, Identifikasi dan Uji Aktivitas Antibakteri Senyawa Golongan Triterpenoid pada Rimpang Temu Putih (Curcuma zedoaria (Berg.) Roscoe). Jurnal Kimia, 4(1): 2026.

Rohaeni NS. 2016. Kajian Konsentrasi Pelarut Terhadap Ekstrak Pigmen dari Sabut Kelapa (Cocos Nucifera L) Sebagai Pewarna Alami. Doctoral Disertation. Fakultas Teknik. Universitas Pasundan.

Sasongko P, Mushollaeni W, Herman H. 2014. Aktivitas Antibakteri Asap Cair dari Limbah Tempurung Kelapa Terhadap Daging Kelinci Asap. Buana Sains, 14(2): 193-197. doi : 10.33366/bs.v14i2.296

Sevindik M, Akgul H, Pehlivan M, Selamoglu Z. 2017. Determination of Therapeutic Potential of Mentha Longifolia ssp. longifolia. Fresen Environ Bull, 26(7): 4757-4763.

Surtiyani M. 2015. Analisis Kadar Asam Cuka Dari Fermentasi Menggunakan S.cerevisiae Dan A.aceti Pada Bonggol Pisang (Musa Paradisiaca L.) Varietas Ambon Nangka, Ambon Bawen Dan Ambon Wulung Yang Hidup Di Jalur Pantai Selatan Desa Tegal Kamulyan Cilacap (Doctoral dissertation, Universitas Muhammadiyah Purwokerto). 50-53.

Tehubijuluw H., Watuguly T., Tuapattinaya PM. 2018. Analisis Kadar Flavonoid Pada Teh Daun Lamun (Enhalus acoroides) Berdasarkan Tingkat Ketuaan Daun. Biopendix: Jurnal Biologi, Pendidikan dan Terapan, 5(1):1-7.

Vongsangnak W, Chauvatcharin GS, Zhong JJ,. 2004. Towards Efficient Extraction of Notoginseng Saponins from Cultured Cells of Panax Notoginseng. Biochemical Engineering Journal, 18(4): 115-120.

Wulandari A, Bahri S, Mappiratu M. 2018. Aktivitas Antibakteri Ekstrak Etanol Sabut Kelapa (Cocos nucifera Linn) Pada Berbagai Tingkat Ketuaan. KOVALEN: Jurnal Riset Kimia, 4(3): 276-284.

Yadav M, Chatterji S, Gupta SK, Watal G. 2014. Preliminary Phytochemical Screening of Six Medicinal Plants Used in Traditional Medicine. International Journal Pharmacy Science, 6(5): 539-542.

Yun T, Pei Q, Xue Z, Yuan L. 2017. Study on Colorimetric Method and Content Determination of Total Phenol in Homemade Plum Wine. Medicinal Plant, 8(1): 22-26. 